\title{
ROOTING ABILITY OF LEAFY-STEM GUTTINGS OF HYBRID SHOREA (DIPTEROCARPACEAE)
}

\author{
Kenzo $\mathrm{T}^{1, *}$, Ichie $\mathrm{T}^{2}$, Kamiya $\mathrm{K}^{3}, \mathrm{Ngo} \mathrm{KM}^{4,5} \& \operatorname{Lum} \mathrm{SKY}^{4,5}$ \\ ${ }^{1}$ Department of Plant Ecology, Forestry and Forest Products Research Institute, Tsukuba, Ibaraki 305-8687, Japan \\ ${ }^{2}$ Faculty of Agriculture, Kochi University, Nankoku, 783-8502, Japan \\ ${ }^{3}$ Faculty of Agriculture, Ehime University, Matsuyama, Ehime 790-0865, Japan \\ ${ }^{4}$ Asian School of the Environment, Nanyang Technological University, 639798, Singapore \\ ${ }^{5}$ Natural Sciences and Science Education Academic Group, National Institute of Education, Nanyang Technological \\ University, 637616, Singapore \\ *mona@affrc.go.jp \\ Submitted July 2018; accepted Jan 2019
}

\begin{abstract}
Although cutting is a useful method for vegetative propagation and tree breeding, there is a difference in rooting ability between tree species and even between node positions within a species. A large number of $\mathrm{F}_{1}$ hybrids of Shorea (Shorea curtisii $\times$ S. leprosula) (Dipterocarpaceae) have recently been found in Singapore. Given that some of the hybrid traits appear to have higher physiological performances than those of their parent species, understanding the rooting ability of the leafy-stem cuttings of $F_{1}$ hybrids may contribute to performance improvement in dipterocarp trees. In this study, we compared the rooting abilities of cuttings taken from seedlings of $F_{1}$ hybrids and their parent species at different node positions. The cuttings of $F_{1}$ hybrids showed rooting ability with small internode differences, and the rooting rate $(32.2 \%)$ was almost intermediate between those of S. curtisii $(42.0 \%)$ and S. leprosula $(21.0 \%)$. The rooting rates of hybrids and parents fell into the middle range of previously reported values for 21 closely related Shorea species. Overall, the rooting ability of $F_{1}$ hybrids is comparable with that of their parent species and/or other Shorea species in the red meranti group. Thus, $\mathrm{F}_{1}$ hybrids could be mass propagated through cuttings.
\end{abstract}

Keywords: Dipterocarp, hybridisation, Shorea curtisii, Shorea leprosula, red meranti, vegetative propagation

\section{INTRODUCTION}

Members of Dipterocarpaceae (dipterocarp trees), particularly species in the genus Shorea, dominate the canopy layers of Southeast Asian tropical rainforests and are important sources of commercial timber (Ghazoul 2016). Although the interspecific hybridisation of dipterocarp species is rare in natural rainforests (Ashton 1969, Thomas 2003), frequent hybridisation has recently been found between three closely related Shorea species in the section Mutica (S. leprosula, $S$. parvifolia and $S$. curtisii) in a small, isolated area of the tropical rainforest in Bukit Timah Nature Reserve, Singapore (Kamiya et al. 2011). Surprisingly, approximately $20 \%$ of the trees that had reached reproductive size were confirmed by DNA analysis to be the $\mathrm{F}_{1}$ hybrids of two locally rare Shorea species (S. leprosula and S. parvifolia), and the proportion of those in the seedling and sapling stages reached 40\% (Kenzo et al. 2016). Moreover, hybrids often exhibit heterosis, such as high growth rates, drought tolerance and characteristics that are superior to those of their parent species (Arnold 2006). The hybrid Shorea seedlings found in Singapore grow best under relatively dry and high irradiance conditions and may therefore have better drought tolerance than their parents (Kenzo et al. 2016).

Leafy-stem cuttings contribute to the mass propagation of tree species and to tree breeding (Hartmann et al. 1997). If seedling cuttings of the Shorea hybrids show high rooting ability and superior characteristics compared to those of the parental species, the cutting method would be beneficial for the improvement of dipterocarp tree breeding. Although cuttings have been used to propagate tropical tree species, such as Acacia spp., Eucalypts spp., Hevea brasiliensis and Tectona grandis, the rooting ability of cuttings drastically varies both within and between tree species (Webster \& Baulkwill 1989, Tewari 1999, 
Kha 2000, Assis et al. 2004, Tate \& Page 2018). In addition, in several species, rooting ability varies according to the age of the stock plant and even the position of the node within the same shoot (Dick and Aminah 1994). For example, the rooting ability of the shoots of young saplings and coppices is generally higher than that of mature trees (Itoh et al. 2003). To develop the appropriate propagation techniques based on cuttings, understanding the rooting ability at different node positions in shoots from young saplings and coppices in each tree species is necessary (Dick \& Aminah 1994).

Given that many dipterocarp species exhibit uncertain reproductive intervals with mast flowering only once every 5 to 10 years (Ichie et al. 2005), the development of leafy-stem cutting techniques for dipterocarp species may provide a stable supply of seedlings for the establishment of commercial and environmental plantations in Southeast Asia (Ahmad 2006). Although stem cuttings from some dipterocarp tree species have been commercialised for plantations in the region, the establishment of cutting techniques for the hybrids of dipterocarp species may enable the production of germplasm with high environmental adaptability and growth ability (Sakai \& Subiakto 2007). Some reports have shown that the rooting ability of dipterocarp trees varies according to the species, tree age and shoot-node position, and that several dipterocarp species lack rooting ability (Momose 1978, Kantarli 1993, Noraini and Liew 1994, Itoh et al. 2003). In the present study, to understand the rooting ability of cuttings from Shorea hybrids, the study 1) compared the rooting ability of leafystem cuttings taken from $\mathrm{F}_{1}$ Shorea hybrids (Shorea curtisii $\times$ S. leprosula) and their parent species at different node positions, and 2) reviewed previous studies on closely related Shorea species (red meranti group) and compared the rooting ability of the hybrids and that of their parent species.

\section{MATERIALS AND METHODS}

\section{Plant materials, study site and cutting preparation}

The $\mathrm{F}_{1}$ hybrids of Shorea (S. curtisii $\times$ S. leprosula) were selected, given that the seedlings of this hybrid are easily found at the Bukit Timah Nature Reserve $\left(1^{\circ} 21^{\prime} \mathrm{N}, 103^{\circ} 46^{\prime} \mathrm{E}\right)$ in Singapore
(Kenzo et al. 2016). The forest vegetation is typical of the coastal hill forests of the southern Malay Peninsula and dominated by members of the family Dipterocarpaceae (Kenzo et al. 2016). Shorea curtisii and S. leprosula produce timber of good quality and are distributed over similar geographical ranges in the Malay Peninsula, Borneo and Sumatra but exhibit different morphological and ecological traits (Ashton 1982). Shorea curtisii dominates ridges in hilldipterocarp forests and occasionally in coastal hill-dipterocarp forests, whereas $S$. leprosula commonly grows on well-drained soil in lowlanddipterocarp and hill-dipterocarp forests (Ashton 1982, Kamiya et al. 2012). These species coexist on the same coastal hills and inland mountain ranges in Malaysia (Symington 2004).

Branches for cuttings were collected from wild ones in Bukit Timah in February 2012. Stock plants were young wild saplings approximately $1-2 \mathrm{~m}$ in height and had grown in large canopy gaps under direct sunlight. The rooting experiment was performed in a laboratory at the National Institute of Education, Nanyang Technological University, Singapore in February 2012. The cuttings were cut to a length of approximately $10 \mathrm{~cm}$ with one leaf and node. The position of each node was also recorded in the cuttings from tip to base of sampled branches sequentially. The leaf area was approximately halved to reduce water loss through transpiration (Aminah et al. 1997a). The ends of the cuttings on the planting media side were dipped into powder that contained $0.1 \%$ naphthyl acetic acid-containing talc to induce rooting (Sakai \& Subiakto 2007). The river sand that had been sterilised through autoclaving was used as a planting medium. The trays containing cuttings were covered with plastic, and humidity was maintained above c.a. 90\% (Aminah et al. 2000). Light intensity was approximately 200 ( $\mu$ mol photon $\mathrm{m}^{-2} \mathrm{~s}^{-1}$ ), which is the preferred light intensity for the rooting of several Shorea species, including S. leprosula (Aminah et al. 1997b). The temperature in the laboratory was controlled approximately from $23-28^{\circ} \mathrm{C}$ by air conditioning. The rooting rate (rooting cuttings/the total cuttings, \%) was investigated 3 months after planting, because the rooting induction of most dipterocarp trees, including Shorea, usually occurs within 3 months after planting (Sakai \& Subiakto 2007). 


\section{Comparison of the rooting rates of related Shorea species by a literature survey}

The rooting ratios of 21 Shorea species in the red meranti group were quantified by literature survey. A total of 256 measurements from 27 reports were collected, including journal papers, proceedings and books. The rooting rate of sections in red meranti such as Brachypterae, Mutica, Ovalis, Rubella and Pachycarpae were also compared, because many ecological and physiological traits such as drought and freezing tolerance and the growth rate significantly varied according to the section even in the same red meranti group (Sasaki 2011).

\section{Statistical analysis}

A $\mathrm{X}^{2}$-test was performed to assess statistically significant differences between the rooting ratios of different species. Fisher's exact test was used to examine the relation between the existence of rooting of each species and the node positions below the apex (Sokal \& Rohlf 1995). All analysis were conducted using SPSS for Windows v 22.

\section{RESULTS}

\section{Differences in rooting ratios between hybrids and their parents}

The cuttings of hybrids (Figure 1A, Table 1) and both parent species (Figure 1B, Table 1) exhibited a capacity to form adventitious roots. Newly developed shoots and leaves were also found in several cuttings (Figure 1C). The rooting ratios of the hybrids and their parent species differed significantly (Table $1, \mathrm{X}^{2}$-test, $\mathrm{X}^{2}=18.3$, d.f. $\left.=2, \mathrm{p}<0.001\right)$. Shorea curtisii $(42.0 \%)$ exhibited the highest rooting ratio, followed by hybrids $(32.3 \%)$ and S. leprosula $(21.0 \%)$.

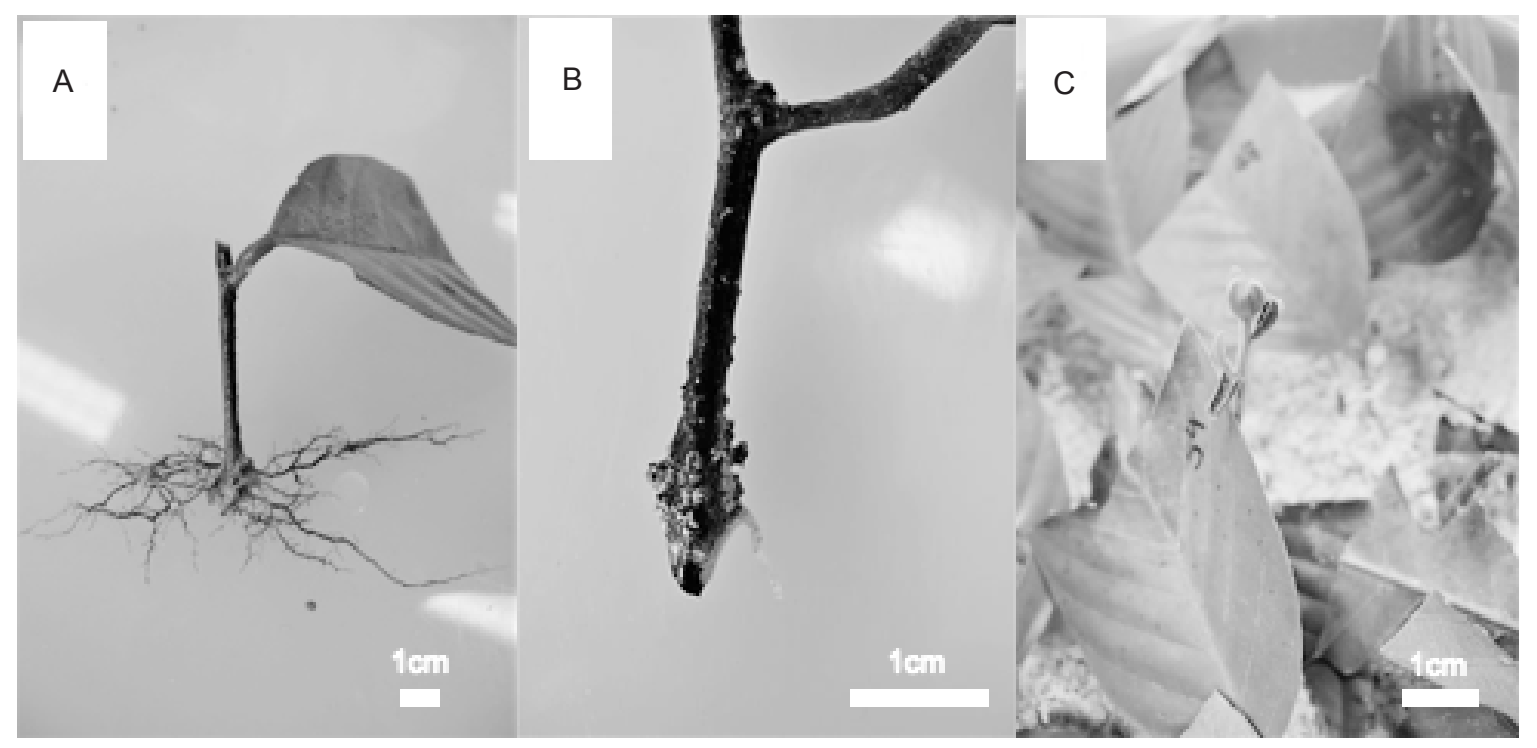

Figure 1 Examples of cuttings after 3 months, $\mathrm{A}=$ a rooted cutting of the $\mathrm{F}_{1}$ hybrid (Shorea curtisii $\times$ S. leprosula), B = a rooted cutting of $S$. curtisii, $\mathrm{C}=$ a new shoot from a cutting of $S$. leprosula

Table 1 Number of the total cuttings, rooted cuttings and rooting rate (\%) after three months

\begin{tabular}{lccc}
\hline Species & Total cuttings & Rooted cuttings & Rooting rate $(\%)$ \\
\hline Hybrid & 115 & 37 & 32.2 \\
Shorea curtisii & 138 & 58 & 42.0 \\
Shorea leprosula & 219 & 46 & 21.0 \\
Total & 472 & 141 & 29.9 \\
\hline
\end{tabular}

There were significant differences in the rooting rate between the parent species and the hybrid $\left(\mathrm{X}^{2}\right.$-test, $\left.\mathrm{X}^{2}=18.3, \mathrm{df}=2, \mathrm{p}<0.001\right)$ 


\section{Differences in the rooting ratios of cuttings taken at different node positions}

The rooting ratios of cuttings taken from different node positions did not differ significantly for hybrids and their parent species (Table 2, Fisher's exact test, $p>0.05$ for all species), though the rooting rate of hybrid cuttings taken from the terminal position was approximately half $(21.4 \%)$ of those from the second to fourth positions $(>40 \%)$.

\section{Comparison of the rooting rates of related Shorea species}

Rooting rates significantly differed between Shorea species (Table 3, 15 species with more than three measurements, ANOVA, $\mathrm{p}<0.05)$. For example, the rooting rate of $S$. ovata in the section Mutica was only $2.3 \%$, while S. balangeran $(68.5 \%)$, S. parvistipulata $(60.0 \%)$, S. platyclados $(65.5 \%)$ and S. selanica $(53.5 \%)$ in the section Brachypterae, S. parvifolia (53.9\%) in the section Mutica, S. ovalis (51.2\%) in the section Ovalis and S. macrophylla (56.4\%) in the section Pachycarpae (Table 3) exhibited rooting rates of more than $50 \%$. Intersectional differences exhibited by the three sections, that included more than five species each, were not significant (Table 4, ANOVA, $p>0.05)$. The average rooting rate of the section Mutica, which includes S. curtisii and S. leprosula, was $31.1 \%$.

\section{DISCUSSION}

\section{Rooting ability of hybrid Shorea}

The rooting ability of the $\mathrm{F}_{1}$ hybrid ( $S$. leprosula $\times S$. curtisii) is intermediate between those of its parent species, which is similar to the intermediate growth and survival rates of Shorea hybrids reported in a natural forest (Kenzo et al. 2016). These results contrast with the growth rate and photosynthesis of the hybrids of several tree species that exhibit heterosis (i.e. superior characteristics compared to their parent species) (Orians et al. 1999). Similar intermediate growth and physiological characteristics have been reported for several hybrid species, such as Salix spp. and Picea spp. (Major et al. 2003, Arnold 2006). On the other hand, the improvement of dipterocarp trees using hybrids may be possible, because obvious heterosis of growth performance have been found in successional hybrids, such as the backcross between parent species and $\mathrm{F}_{1}$ hybrids $(S$. leprosula $\times S$. curtisii) under nursery conditions (Kenzo et al. 2019).

The similarity in rooting ability between node positions in Shorea hybrid and parent species indicated that cutting propagation is possible regardless of node positions except, in some instances, for the first node from the shoot apex. The rooting ability of cuttings taken from some Shorea species at the first node from the shoot apex is low (Aminah 1990). Noraini and

Table 2 Number of total cuttings (TC), rooted cuttings (RC) and rooting rate (RR) in each node position below the apex

\begin{tabular}{|c|c|c|c|c|c|c|c|c|c|}
\hline \multirow{2}{*}{$\begin{array}{l}\text { Species } \\
\text { node position }\end{array}$} & \multicolumn{3}{|c|}{ Hybrid } & \multicolumn{3}{|c|}{ Shorea curtisii } & \multicolumn{3}{|c|}{ Shorea leprosula } \\
\hline & TC & $\mathrm{RC}$ & $\mathrm{RR}(\%)$ & TC & $\mathrm{RC}$ & $\operatorname{RR}(\%)$ & TC & $\mathrm{RC}$ & $\mathrm{RR}(\%)$ \\
\hline 1 & 28 & 6 & 21.4 & 37 & 15 & 40.5 & 41 & 8 & 19.5 \\
\hline 2 & 22 & 9 & 40.9 & 33 & 12 & 36.4 & 38 & 8 & 21.1 \\
\hline 3 & 17 & 7 & 41.2 & 19 & 8 & 42.1 & 33 & 7 & 21.2 \\
\hline 4 & 14 & 7 & 50.0 & 15 & 10 & 66.7 & 29 & 4 & 13.8 \\
\hline 5 & 9 & 2 & 22.2 & 12 & 5 & 41.7 & 23 & 8 & 34.8 \\
\hline 6 & 8 & 1 & 12.5 & 8 & 4 & 50.0 & 15 & 3 & 20.0 \\
\hline $7<$ & 17 & 5 & 29.4 & 14 & 4 & 28.6 & 40 & 8 & 20.0 \\
\hline Fisher's exact test & \multicolumn{3}{|c|}{$\mathrm{P}=0.37$} & \multicolumn{3}{|c|}{$\mathrm{P}=0.50$} & \multicolumn{3}{|c|}{$\mathrm{P}=0.76$} \\
\hline
\end{tabular}

There were no significant differences in the rooting rate between the positions of the hybrid and parent species (Fisher's exact test, $\mathrm{p}>0.05$ ) 
Table 3 Average rooting rate (RR), minimum (Min) and maximum (Max) rooting rates among 21 species in the red meranti group of Shorea (Dipterocarpaceae)

\begin{tabular}{|c|c|c|c|c|c|c|}
\hline Species & Section & $\begin{array}{l}\mathrm{RR} \\
(\%)\end{array}$ & $\begin{array}{l}\text { Min } \\
(\%)\end{array}$ & $\begin{array}{l}\operatorname{Max} \\
(\%)\end{array}$ & $\begin{array}{l}\text { Number of } \\
\text { experiment }\end{array}$ & References* \\
\hline Shorea balangeran & Brachypterae & $68.5 \pm 9.8^{a b c}$ & 43.0 & 91.0 & 4 & 22 \\
\hline Shorea johorensis & Brachypterae & $42.7 \pm 8.5^{\mathrm{abcd}}$ & 0.0 & 79.0 & 9 & $14,18,21,22,26$ \\
\hline Shorea parvistipulata & Brachypterae & $60.0^{\mathrm{N} / \mathrm{A}}$ & - & - & 1 & 22 \\
\hline Shorea pauciflora & Brachypterae & $29.5 \pm 5.3 \mathrm{bcd}$ & 0.0 & 99.0 & 30 & $3,13,18,21,22,26,27$ \\
\hline Shorea platyclados & Brachypterae & $65.5 \pm 4.3^{\mathrm{abc}}$ & 50.0 & 77.0 & 6 & $2,22,24$ \\
\hline Shorea pubistyla & Brachypterae & $7.0^{\mathrm{N} / \mathrm{A}}$ & - & - & 1 & 16 \\
\hline Shorea selanica & Brachypterae & $53.5 \pm 8.8^{\mathrm{abcd}}$ & 30.0 & 69.0 & 4 & 22 \\
\hline Shorea smithiana & Brachypterae & $34 \pm 14.6^{\mathrm{abcd}}$ & 0.0 & 65.0 & 4 & 21,22 \\
\hline Shorea acuminata & Mutica & $43.4 \pm 6.5^{\mathrm{abc}}$ & 0.0 & 83.0 & 26 & $1,13,20,22,27$ \\
\hline Shorea curtisii & Mutica & $20.5 \pm 3.8^{\text {abcd }}$ & 12.0 & 32.0 & 6 & 19 \\
\hline Shorea leprosula & Mutica & $44.4 \pm 3.1$ abcd & 0.0 & 94.0 & 70 & $1,2,4-8,13,18,19,21,22,24,26,27$ \\
\hline Shorea macroptera & Mutica & $22.3 \pm 5.1^{\mathrm{cd}}$ & 0.0 & 48.0 & 14 & $2,10,13,14,27$ \\
\hline Shorea ovata & Mutica & $2.3 \pm 0.9^{\mathrm{d}}$ & 0.0 & 5.0 & 8 & 13,27 \\
\hline Shorea parvifolia & Mutica & $53.9 \pm 4.6^{\text {a }}$ & 0.0 & 83.0 & 27 & $1,2,10,14,20-22,26$ \\
\hline Shorea ovalis & Ovalis & $51.2 \pm 9.7^{a b c}$ & 0.0 & 80.0 & 9 & $1,2,9,18,22$ \\
\hline Shorea beccariana & Pachycarpae & $30.0^{\mathrm{N} / \mathrm{A}}$ & 30.0 & 30.0 & 1 & 14 \\
\hline Shorea macrophylla & Pachycarpae & $56.4 \pm 4.5^{\mathrm{a}}$ & 12.8 & 81.0 & 20 & $12,16,17,22$ \\
\hline Shorea pinanga & Pachycarpae & $39.0 \pm 5.0^{\mathrm{N} / \mathrm{A}}$ & 34.0 & 44.0 & 2 & 22,23 \\
\hline Shorea splendida & Pachycarpae & $49.0^{\mathrm{N} / \mathrm{A}}$ & - & - & 1 & 11 \\
\hline Shorea stenoptera & Pachycarpae & $26.0^{\mathrm{N} / \mathrm{A}}$ & - & - & 1 & 22 \\
\hline Shorea albida & Rubella & $26.1 \pm 6.3$ abcd & 3.6 & 77.8 & 12 & 15,16 \\
\hline All species & & $41.3 \pm 1.7$ & 0.0 & 99.0 & 256 & \\
\hline
\end{tabular}

Different letters indicate significant differences between species ( 15 species tested in more than three experiments, ANVOVA with Bonferroni test, $\mathrm{p}<0.05) ; \mathrm{N} / \mathrm{A}=$ not applicable to the statistical result; scientific names and phylogeny were according to Ashton (1982) and Kamiya et al. (2005); *references are, 1= Ahmad 2006, $2=$ Aminah 1991, $3=$ Aminah 1995, $4=$ Aminah et al. 1995, $5=$ Aminah et al. 1997a, $6=$ Aminah et al. 1997b, $7=$ Aminah et al. 1999, $8=$ Aminah et al. 2000, $9=$ Aminah et al. 2005, $10=$ Aminah et al. 2006, $11=$ Brodie 2003, $12=$ Chai 2003, $13=$ FDPM et al. 1996, $14=$ Itoh et al. 2002, 15 = Kitaoka et al. 2011, 16 = Latifa \& Kasik 2000, $17=$ Lo 1985, 18 = Nakamura \& Kimura 1996, 19 = Noraini \& Liew 1997, 20 = Noraini \& Ling 1993, 21 = Priadjati et al. 2001, 22 = Sakai \& Subiakto 2007, $23=$ Sakai \& Yamamoto 1995, 24 = Sakai et al. 2002, 25 = Srivastava \& Manggil 1981, 26 = Tolkamp \& Priadjati 1996, 27 = Yamate \& Hirasawa 1995

Table 4 Average rooting rate among sections of the red meranti group of Shorea (Dipterocarpaceae)

\begin{tabular}{|c|c|c|c|c|}
\hline Section & $\begin{array}{l}\text { Rooting rate } \\
(\%)\end{array}$ & $\begin{array}{l}\text { Minimum rooting } \\
\text { rate }(\%)\end{array}$ & $\begin{array}{c}\text { Maximum rooting } \\
\text { rate }(\%)\end{array}$ & Number of species \\
\hline Brachypterae & $45.1 \pm 7.4$ & 7.0 & 68.5 & 8 \\
\hline Mutica & $31.1 \pm 7.9$ & 2.3 & 53.2 & 6 \\
\hline Ovalis & 51.2 & - & - & 1 \\
\hline Pachycarpae & $40.1 \pm 5.7$ & 26.0 & 56.5 & 5 \\
\hline Rubella & 26.1 & - & - & 1 \\
\hline
\end{tabular}

There were no significant differences between sections (ANVOVA, $p>0.05$ ) 
Liew (1997) also found that the rooting rate of the node from the terminal position of each seedling shoot was lower compared to that from the middle position in S. curtisii. In this study, the rooting rate of hybrid cuttings taken from the terminal position was approximately half $(21.4 \%)$ of those from the second to fourth positions $(>40 \%)$. This reduction, however, was not obvious in the parent species. Although clear reasons for the different rooting abilities of cuttings taken from different node positions are not known, the growth environment, starch content, node concentration and the shoot age of a stock plant may affect rooting abilities (Dick \& Aminah 1994). The relatively higher average rooting rate of $S$. curtisii $(42 \%)$ than that of the hybrids (32\%) and S. leprosula (21\%) may be related to their high-sprouting ability during the sapling stage. High-sprouting species usually store large amounts of resources, such as starch and nitrogen, in their shoots and roots (Kenzo et al. 2013) and these stored resources may also facilitate cuttings' survival and rooting (Dick \& Aminah 1994). In the Bukit Timah forest, the saplings of $S$. curtisii exhibit higher sprouting rates than other species (e.g. the sprouting rate of $S$. curtisii is $46 \%$, whereas those of hybrid and S. leprosula are less than 20\%). Thus, highsprouting rate of $S$. curtisii saplings may be indicative of the high resource storage that may support the high rooting ability of this species, though the high sprouting rate may also effect adventitious root development (Dick \& Aminah 1994).

\section{Rooting ability among related Shorea species and sections in red meranti}

Although interspecific rooting rates varied widely from $2 \%$ in S. ovata to $69 \%$ in S. balangeran among 21 Shorea species in the red meranti group, the hybrid in the present study had intermediate rooting ability (32\%) in the group. This rooting rate indicates that Shorea hybrid seedlings may be mass-propagated through cuttings. By contrast, the rooting rates of parent species differed from those previously reported. For example, it was found that the rooting rate of S. curtisii was $42 \%$, but Noraini and Leiw (1997) reported a rate of $20.5 \%$. The rooting rate of S. leprosula $(21 \%)$ was approximately half of the previously reported values $(44 \%)$, though the rates varied from $0 \%$ to $94 \%$ among the reports. The different rooting rates observed in previous studies may be attributed to large variations in the size, age and growth conditions of stock plants, planting media, nursery conditions and applied hormones. On the other hand, small intersectional differences in the rooting rates of the red meranti group indicate that the rooting rate is more speciesspecific than section-specific (Dick \& Aminah 1994). However, phylogenetically dependent rooting ability may exist in some Shorea groups as shown by the different rooting and sprouting abilities observed in the bare-root planting experiment performed by Mori (1980). For example, species in the Anthoshorea group (white meranti group), such as $S$. assamica, $S$. brlacteolata, S. hypochra and S. roxburghii, may have higher rooting abilities and more starch reserves than those in the red meranti group (Mori 1980). The former species exhibited high rooting rates (usually more than $80-100 \%$ ) (Aminah 1991, Tolkamp \& Priadjati 1996). Mori (1980) and Sasaki (2011) hypothesised that species distributed over seasonal tropical forests (e.g. Anthoshorea group) have high rooting ability given their large amounts of stored resources that confer high tolerance to stress and disturbance, such as fire and drought in the forests. In fact, $S$. obtusa, which is a typical dry deciduous forest species, has almost $100 \%$ rooting ability (Smits 1983). Further studies on the rooting ability and resource storage of cuttings among various sections of Shorea species, including those distributed over seasonal tropical forests, may improve the current understanding of the cutting traits and success of the mass propagation of various Shorea species, including hybrids, in tropical Asia.

\section{CONCLUSIONS}

The rooting ability of $F_{1}$ hybrid cuttings is intermediate between those of their parent species ( $S$. curtisii and S. leprosula), indicating its negligible heterosis. A small difference in the rooting rate between node positions also indicated that the hybrid and parent species studied can be successfully propagated through cuttings taken across most node positions. The rooting rates of hybrids and parents fell into the middle range of previously reported values for closely related 21 Shorea species (red meranti group). Thus, $\mathrm{F}_{1}$ hybrids could be masspropagated through cuttings. 


\section{ACKNOWLEDGEMENTS}

The authors would like to thank the National Parks Board, Singapore, Center for Tropical Forest Science - Arnold Arboretum Asia Program and the National Institute of Education, Singapore, for their kind support towards the study. This study was conducted with permission from National Parks Board, Singapore (NP/ RP 857, 972-1 to -7). The authors would also like to thank Sano M and Tanaka-Oda A for their kind support towards the study. This work was partly supported by JSPS KAKENHI Grant (21780155, 24688017, 16K07795, 17H04623 \& 17H04602), and by the Environment Research and Technology Development Fund (RF-1010, S-9), Ministry of the Environment, Japan.

\section{REFERENCES}

Ahmad DH. 2006. Vegetative propagation of dipterocarp species by stem cuttings using a very simple technique. Pp 69-77 in Suzuki K et al. (eds) Plantation Technology in Tropical Forest Science. Springer, Tokyo.

Амinah H. 1990. A note on the rooting of Shorea bracteolata stem cuttings. Journal of Tropical Forest Science 3: 187-188.

AminaH H. 1991. Rooting ability of stem cuttings of eleven dipterocarp species. Malaysian Applied Biology 20: 155-159.

Aminah H. 1995. Rooting of Shorea pauciflora stem cuttings from coppice shoots. Journal of Tropical Forest Science 8: 134-136.

Aminah H, Dick JM, Leakey RRB et al. 1995. Effect of indole butyric acid (IBA) on stem cuttings of Shorea leprosula. Forest Ecology and Management 72: 199-206.

Aminah H, Dick JM \& Grace J. 1997a. Rooting of Shorea leprosula stem cuttings decreases with increasing leaf area. Forest Ecology and Management 91: 247-254.

AminaH H, Dick JM \& GRACE J. 1997b. Influence of irradiance on water relations and carbon flux during rooting of Shorea leprosula leafy stem cuttings. Tree Physiology 17: 445-452.

Aminah H, Dick JM \& Grace J. 1999. Effect of photon irradiance and fertiliser levels on the growth of Shorea leprosula stock plants and the rooting ability of their subsequent stem cuttings. Journal of Tropical Forest Science 11: 79-99.

Aminah H, Dick JM, Grace J et al. 2000. The influence of misting frequencies on the water relations and rooting physiology of Shorea leprosula leafy stem cuttings. Journal of Tropical Forest Science 12: 431-443.

Aminah H, Azwani AAF \& Hamzah M. 2005. Effects of media on leafy stem cuttings of Shorea ovalis (Meranti Kepong). Malaysian Forester 68: 174-179.

Aminah H, Hasnita RN \& Hamzah M. 2006. Effects of indole butyric acid concentrations and media on rooting of leafy stem cuttings of Shorea parvifolia and Shorea macroptera. Journal of Tropical Forest Science 18: 1-7.
ARNold ML. 2006. Evolution Through Genetic Exchange. Oxford University Press, Oxford.

Ashton PS. 1969. Speciation among tropical forest trees: some deductions in the light of recent evidence. Biological Journal of the Linnean Society 1: 155-196.

Ashton PS. 1982. Dipterocarpaceae. Pp 237-552 in Van-Steenis CGGJ (ed) Flora Malesiana, Ser. 1 Spermatophyta. Vol. 9(2), Martinus Nijhoff Publishers, Dordrecht.

Assis TF, Fett-Neto AG \& Alfenas AC. 2004. Current techniques and prospects for the clonal propagation of hardwoods with emphasis on Eucalyptus. Pp 303-333 in Walter C \& Carson M (eds) Plantation Forest Biotechnology for the 21st Century. Research Signpost, Kerala.

Brodie JF. 2003. Factors affecting the rooting ability of Dryobalanops oblongifolia and Shorea splendida (Dipterocarpaceae) stem cuttings. Journal of Tropical Forest Science 15: 109-116.

CHAI EOK. 2003. Mass vegetative propagation research of Shorea macrophylla (Enkabang Jantong) by cuttings at the Sarawak indigenous tree center (SITC), Tatau, Sarawak, Malaysia. Pp 179-187 in Aminah H et al. (eds) Proceedings of the Seventh Round-Table Conference on Dipterocarps, APAFRI, Kuala Lumpur.

Dick JM \& Aminah H. 1994. Vegetative propagation of tree species indigenous to Malaysia. The Commonwealth Forestry Review 73: 164-171.

Fdpm, (Forestry Department Peninsular Malaysia), Psfd (Perak State Forestry Department) \& Jica (Japan International Cooperation Agency). 1996. 5 Year Report (1991-1996) on the Multi-Storied Forest Management Project in Peninsular Malaysia. Forestry Department Peninsular Malaysia (FDPM), Perak State Forestry Department (PSFI) \& Japan International Cooperation Agency (JICA), Kuala Lumpur.

Ghazoul J. 2016. Dipterocarp Biology, Ecology and Conservation. Oxford University Press, Oxford.

Hartmann HT, Kester DE, Davies FT et al. 1997. Plant Propagation: Principles and Practices. $6^{\text {th }}$ edition. Prentice-Hall Inc., New Jersey.

Ichie T, Kenzo T, Kitahashi Y et al. 2005. How does Dryobalanops aromatica supply carbohydrate resources for reproduction in a masting year? Trees 19: 704-711.

Itoh A, Yamakura T, TAN S ET AL. 2003. Effects of resource plant size on rooting of Dryobalanops lanceolata cuttings. Journal of Forest Research 8: 117-121.

Itoh A, Yamakura T, KanZaKi M eT AL. 2002. Rooting ability of cuttings relates to phylogeny, habitat preference and growth characteristics of tropical rainforest trees. Forest Ecology and Management 168: 275-287.

Kamiya K, Harada K, Tachida H et al. 2005. Phylogeny of PgiC gene in Shorea and its closely related genera (Dipterocarpaceae), the dominant trees in Southeast Asian tropical rain forests. American Journal of Botany 92: 775-788.

KamiYa K, Gan YY, Lum SK et AL. 2011. Morphological and molecular evidence of natural hybridization in Shorea (Dipterocarpaceae). Tree Genetics and Genomes 7: 297-306.

Kamiya K, Nanami S, Kenzo T et al. 2012. Demographic history of Shorea curtisii (Dipterocarpaceae) inferred from chloroplast DNA sequence variations. Biotropica 44: 577-585. 
Kantarli M. 1993. Vegetative Propagation of Dipterocarps by Cuttings in ASEAN Region. Review Paper No. 1, ASEAN-Canada Forest Tree Seed Centre Project, Saraburi.

Kenzo T, IChIE T, Yoneda R ET AL. 2013. Ontogenetic changes in carbohydrate storage and sprouting ability in pioneer tree species in Peninsular Malaysia. Biotropica 45: 427-433.

Kenzo T, Ichie T, Norichika Y et al. 2016. Growth and survival of hybrid dipterocarp seedlings in a tropical rain forest fragment in Singapore. Plant Ecology and Diversity 9: 447-450.

Kenzo T, Kamiya K, Ngo KM et al. 2019. Overlapping flowering periods among Shorea species and high growth performance of hybrid seedlings promote hybridization and introgression in a tropical rainforest of Singapore. Forest Ecology and Management. 435: 38-44.

Kitaoka A, Uchida Y \& Asaishi H. 2011. Production of cuttings in a peat swamp species from Sarawak, Malaysia. Pp 89-99 in Suzuki K et al. (eds) Plantation Technology in Tropical Forest Science. Springer, Tokyo.

KHA LD. 2000. Studies on natural hybrids of Acacia mangium and A. auriculiformis in Vietnam. Journal of Tropical Forest Science 12: 794-803.

Latifah T \& Kasik V. 2000. A study of the vegetative propagation of some indigenous tree species in Sarawak. Pp 126-129 in Ogino K et al. (eds) Proceedings of Workshop on Forest Ecosystem Rehabilitation, Kuching. Forest Department Sarawak, Kuching.

Lo YN. 1985. Root initiation of Shorea macrophylla cuttings: effect of node position, growth regulators and misting regime. Forest Ecology and Management 12: $42-52$.

Major Je, Mosseler A, Barsi DC et al. 2003. Morphometric, allometric and developmentally adaptive traits in red spruce and black spruce. II. Seedling and mature tree assessment of controlled intra-and interspecific hybrids. Canadian journal of Forest Research 33: 897-909.

Momose Y. 1978. Vegetative propagation of Malaysian trees. Malaysian Forester 41: 219-223.

Mori T. 1980. Physiological Studies on Some Dipterocarp Species of Peninsula Malaysia as a Basis for Artificial Regeneration. Research Pamphlet No. 78, Forestry Department Peninsula Malaysia, Kuala Lumpur.

Nakamura K \& Kimura S. 1996. Technique of vegetative propagation on dipterocarps. Tropical Forestry 36: 37-46.

Noraini ABS \& LiEw TS. 1994. Effects of plant materials, cutting positions, rooting media and IBA on rooting of Shorea leprosula (Dipterocarpaceae) Cuttings. Pertanika Journal of Tropical Agricultural Science 17: 49-53.

Noraini ABS \& Liew TS. 1997. Anatomical evidence of rooting ability of Shorea leprosula MiQ. and Shorea curtisii Dyer ex King cuttings. Malaysian Forester 60: $38-45$.
NorAInI ABS \& Ling TT. 1993. A note on the rooting of Shorea acuminate and Shorea parvifolia leafy stem cuttings. Journal of Tropical Forest Science 6: 206-208.

Orians CM, Bolnick DI, Roche BM et AL. 1999. Water availability alters the relative performance of Salix sericea, Sralix eriocephala, and their $\mathrm{F}_{1}$ hybrids. Canadian Journal of Botany 77: 514-522.

Priadjati A, Smits WT \& Tolkamp GW. 2001. Vegetative propagation to assure a continuous supply of plant material for forest rehabilitation. Pp 19-30 in Hillegers PJM \& Iongh HHD (eds) The Balance Between Biodiversity Conservation and Sustainable Use of Tropical Rain Forests. The Tropenbos Foundation, Wageningen.

Sakai C \& Subiakto A. 2007. Manual of Mass Propagation Technique of Dipterocarps Species by KOFFCO System. The collaboration project among FORDA, JICA, Komatsu Ltd, Bogor.

Sakai C, Subiakto A, Nuroniah HS et al. 2002. Mass propagation method from the cutting of three dipterocarp species. Journal of Forest Research 7: 73-80.

Sakai C \& Yамамото Y. 1995. Vegetative propagation of dipterocarps. Tropical Forestry 33: 23-29.

SASAKI S. 2011. Ecology and physiology of Dipterocarpaceae. Pp 3-22 in Suzuki K et al. (eds) Plantation Technology in Tropical Forest Science. Springer, Tokyo.

SmITs WTHM. 1983. Vegetative propagation of Shorea obtusa and Agathis dammara by means of leaf cuttings and stem cutting. Malaysian Forester 46: 175-185.

SOKal RR \& Rohlf FJ. 1995. Biometry. The Principles and Practice of Statistics in Biological Research. $3^{\text {rd }}$ edition. W. H. Freeman and Company, New York.

SRIVASTAVA PBL \& MANGgiL P. 1981. Vegetative propagation of dipterocarps. Malaysian Forester 44: 301-313.

Symington CF. 2004. Foresters' Manual of Dipterocarps. Second edition. Malayan Forest Records 16. Forest Research Institute Malaysia, Kuala Lumpur.

TAte HT \& Page T. 2018. Cutting propagation of Santalum austrocaledonicum: the effect of genotype, cutting source, cutting size, propagation medium, IBA and irradiance. New Forests 49: 551-570.

TEWARI DN. 1999. A Monograph on Teak (Tectona grandis Linn.f.). International Book Distributors, Dehradun.

Thomas SC. 2003. Comparative biology of tropical trees: a perspective from Pasoh. Pp 171-194 in Okuda T et al. (eds) Pasoh: Ecology of a Lowland Rain Forest in Southeast Asia. Springer, Tokyo.

Tolkamp GW \& Priadjati A. 1996. The effect of different stock plant types (hedge orchards) and cutting media on the rooting ability of 14 Dipterocarp species. Pp 197-215 in Appanah S \& Khoo KC (eds) Proceedings of the Fifth Round Table Conference on Dipterocarps. Chiang Mai, Thailand 7-10 November 1994. Forest Research Institute Malaysia, Kuala Lumpur.

Webster CC \& Baulkwill WJ. 1989. Rubber. Tropical Agriculture Series. Longman Science \& Technical, Essex.

Yamate H \& Hirasawa T. 1995. Rooting of cuttings of dipterocarps. Tropical Forestry 33: 48-52. 